\title{
PENTINGNYA MATERI LINGKUNGAN
}

\section{DALAM PEMBELAJARAN BAHASA INDONESIA}

\author{
Vira Agustin \\ Universitas Negeri Padang _ Fakultas Bahasa dan Seni \\ agustinvira999@gmail.com
}

Pembelajaran bahasa indonesia adalah pembelajaran wajib yang harus diikuti seluruh siswa yang menduduki jenjang pendidikan formal. Pembelajaran Bahasa Indonesia merupakan salah satu materi pelajaran yang sangat penting di sekolah. Tujuan pembelajaran bahasa Indonesia adalah agar siswa memiliki kemampuan berbahasa Indonesia yang baik dan benar serta dapat menghayati bahasa dan sastra Indonesia sesuai dengan situasi dan tujuan berbahasa serta tingkat pengalaman siswa sekolah dasar (Akhadiah, 1991: 1)

Lingkungan adalah sesuatu yang ada di alam sekitar yang memiliki makna dan/atau pengaruh tertentu kepada individu. Lingkungan menurut KBBI adalah semua yang mempenaruhi pertumbuhan manusia atau hewan, maka dalam dunia pembelajaran dibutuhkan pengetahuan mengenai lingkungan. Sedangkan menurut Ramadhan (2019) menjelaskan bahwa pendidikan lingkungan adalah upaya bersama yang secara sadar diselenggarakan untuk mengajarkan atau menarik perhatian manusia tentang bagaimana fungsi lingkungan alam dan bagaimana manusia ini dapat mengelola dan juga melindunginya. Sejalan dengan hal tersebut Tulalessy (2016) Pendidikan lingkungan hidup (Environmental Education) adalah suatu proses untuk membangun populasi manusia di dunia yang sadar dan peduli terhadap lingkungan secara total (keseluruhan) dan segala masalah yang berkaitan dengannya, dan masyarakat yang memiliki pengetahuan, keterampilan, sikap dan tingkah laku, motivasi serta komitmen untuk bekerja sama, baik secara individu maupun kolektif untuk dapat memecahkan berbagai permasalahan lingkungan saat ini, dan mencegah timbulnya masalah baru.

Ramadhan (2019) mengatakan bahwa "environmental problems are inherently inseparable from environmental awareness, values, and attitudes of people. This encourages 
countries to start assessing environmental education”, maksudnya adalah Masalah lingkungan sejatinya tidak dapat dilepaskan dari kesadaran, nilai, dan nilai lingkungan sikap manusia . Hal ini mendorong negara untuk memulai menerapkan pendidikan. Lingkungan atau environment adalah mencakup segala hal yang ada di sekitar kita. Sejalan dengan itu Ramadhan (2019) juga mengemukakan pendidikan lingkungan dapat membantu siswa memikirkan kembali hubungan antara manusia dan lingkungan, memahami lingkungan, menyadari masalah lingkungan, dan mempertimbangkan masalah lingkungan yang berkaitan dengan kehidupan. Pendidikan tidak hanya tentang ilmu yang didapatkan namun juga untuk menerapkannya pada lingkungan sekitar.

Materi lingkungan dalam pembelajaran bahasa indonesia menjadi hal yang penting, sebab sangat bayak dampak positif yang akan didapatkan jika materi lingkungan dalam pembelajaran bahasa Indonesia. Dampak positif yang didapatkan diantaranya adalah pertama, siswa dapat mengtahui lebih banyak pengetahuan mengenai lingkungan sekitar dengan berbagai permasalahannya, sehingga siswa juga dapat memberikan kontribusi dalam pemecahan masalah tersebut. Han tersebut digambarkan oleh Hauchild S, Poltavthenko E, dan Stoller F, L (dalam Ramadhan et.al, 2019), dengan mengintegrasikan pendidikan lingkungan ke dalam kelas, guru dapat meningkatkan minat siswa terhadap permasalahan kontemporer yang mungkin langsung mempengaruhi masa depan mereka. Menurut Widaningsih (dalam Landyani, 2014: 82) "Secara formal pendidikan lingkungan hidup menjadi salah satu alternatif yang rasional untuk memasukkan pendidikan lingkungan ke dalam kurikulum." Hal tersebut disebebkan pendidikan lingkungan hidup adalah faktor yang penting dalam mengelola lingkungan hidup dan sebagai perantara dalam menghasilkan sumber daya manusia dalam membangun kehidupan yang lebih baik di masa depan.

Kedua, siswa dapat memahami akan pentingnya lingkungan bagi manusia. Manusia sangat bergantung dengan lingkungan hidupnya, baik lingkungan fisik maupun lingkungan sosial. Materi lingkungan dalam pembelajaran bahasa Indonesia tentu saja dapat memberikan pelajaran kepada siswa tentang pengetahuan mengenai cara-cara agar lingkungan tetap terjaga. Selain itu Pembelajaran lingkungan hidup merupakan upaya melestarikan dan menjaga lingkungan serta ekosistem kehidupan makluk hidup yang dapat memberikan kontribusi pada keberlangsungan kehidupan yang seimbang dan lebih harmonis. 
Ketiga, Materi lingkungan dalam pembelajaran bahasa indonesia dapat digunkan sebagai media mengasah pola pikir siswa dalam mengembangkan teks maupun dalam memahami teks. Seperti yang dikemukakan oleh Daryanto dan Suprihatin (2013:1) Materi pendidikan lingkungan hidup merupakan alternatif pilihan untuk diterapkan kepada peserta didik agar dapat mengembangkan pola pikir dan bertindak, berperilaku sehat secara fisik dan mental dalam kehidupan sehari-hari. Setelah mempelajari materi lingkungan dalam pembeljaran maka siswa akan medapatkan model yang harus ditiru dalam bertindak, terkhusus tindakan-tidakan yang berhubungan dengan lingkungan. Contohnya adalah saat berada pada lingkungan alam, apa saja hal-hal yang boleh dilakukan dan hal-hal yang tidak boleh dilakukan seperti bagaimana harus membuang sampah di lingkungan alam. Sejalan dengan hal tersebut Ramadhan (2018) mengemukakan "The environmental approach is one deep approach a suitable Indonesian lesson learned in narrative writing”, maksudnya adalah pendekatan lingkungan adalah salah satu pendekatan mendalam untuk pembelajaran bahasa Indonesia yang cocok penulisan naratif. Tema lingkungan dapat dijadikan salah satu alternatif dalam pembelajaran menulis teks naratif.

Sejalan dengan hal itu, materi lingkungan dapat menjadi alternatif dalam mengembangkan pola pikir siswa dalam mengembangkan sebuah teks, misalnya mengembangkan atau memproduksi teks laporan hasil observasi. Bahasa tentunya tidak akan lepas dari konteks dan teks (Agustina, 2017). Saat guru memberikan materi mengenai teks laporan hasil observasi maka guru bisa mengarahkan siswa unruk memproduksi teks laporan hasil observasi dengan tema lingkungan, selain mengembangkan pola pikir, siswa juga dapat membentuk kecerdasan hati dan pikiran saat melaksanakan tugas tersebut. Seperti yang dikemukakakan oleh Putri dan Ramadahan (2019) teks laporan hasil observasi merupakan jenis teks yang melaporkan atau menyampaikan hasil suatu pengamatan secara umum. Teks laporan hasil observasi memaparkan hasil pengamatan secara sistematik dan objektif berdasarkan kenyataan atau fakta yang ada. Mendidik bermakna membentuk watak dengan nilai-nilai hidup (Ramadhan: 2020), terutama kesadaran dalam menjaga lingkungan. Belajar pada hakikatnya adalah suatu interaksi antara individu dengan lingkungan. Lingkungan sebagai sumber belajar yang tidak terbatas dalam memberikan pengetahuan kepada peserta didik sehingga semakin kita gali semakin banyak yang didapatkan hal yang dapat dipelajari. Halimah, Lely (2008) mengungkapkan bahwa pemanfaatan lingkungan sebagai sumber belajar selama proses pembelajaran bahasa Indonesia telah terbukti kondusif dapat memberikan kesempatan kepada 
peserta didik untuk berpartisipasi secara aktif menggunakan bahasa Indonesia secara komunikatif dalam berbagai aktivitas dalam kegiatan pembelajaran.

Penulis telah menyebarkan angket mengenai kaitan pembelajaran bahasa Indonesia dengan lingkungan kepada sejumlah mahasiswa dari berbagai perguruan tinggi. Berdasarkan hasil penelitian penulis terhadap sedikitnya 65 orang mahasiswa. Butir satu, bahwa materi lingkungan perlu ditambahkan dalam pembelajaran bahasa Indonesia, yang menyatakan setuju $(54,5 \%)$, sangat setuju $(42,42 \%)$, kurang setuju (1,52\%) dan tidak setuju $(1,52 \%)$. Butir dua, bahwa tema lingkungan sangat dekat dengan pembelajaran bahasa Indonesia, yang menyatakan setuju(63,6\%) sangat setuju $(33,33 \%)$, kurang setuju $(1,52 \%)$ dan tidak setuju $(1,52 \%)$. Butir tiga setuju bahwa manusia sangat bergantung pada lingkungan hidupnya, fisik maupun sosial yang menyatakan sangat setuju $(65,15 \%)$, setuju $(31,82 \%)$ kurang setuju $(1,52 \%)$ dan tidak setuju (1,52\%). Butir empat setuju bahwa mengaitkan pembelajaran bahasa Indonesia dengan lingkungan adalah salah satu strategi yang tepat untuk dapat memecahkan persoalan lingkungan yang di Indonesia, yang menyatakan sangat setuju (65,15\%), setuju $(31,82 \%)$ kurang setuju $(1,52 \%)$ dan tidak setuju $(1,52 \%)$. Butir lima bahwa dengan pembelajaran bahasa Indonesia memproduksi teks bertema lingkungan, dapat memperkaya wawasan ekologis siswa, yang menyatakan setuju (50\%), sangat setuju (45,5\%) tidak setuju (5\%) dan kurang setuju (0\%). Butir enam, setuju bahwa lingkungan dapat memicu berbagai ilmu pengetahuan manusia baik secara khusus maupun kebahasaan (menyimak, menulis, berbicara, dan membaca), yang menyatakan setuju (50\%), sangat setuju (47\%) kurang setuju (1,52\%) dan tidak setuju (1,52\%). Butir tujuh bahwa teks-teks lingkungan adalah konvensi sosial, sekaligus pembangun dan penerus makna dan nilai, yang menyatakan setuju (66,7\%), sangat setuju $(30,3 \%)$ kurang setuju $(1,52 \%)$ dan tidak setuju (1,52\%). Butir delapan, bahwa pembelajaran dan pengajaran bahasa Indonesia sudah selayaknya berbasiskan Lingkungan, yang menyatakan setuju $(71,2 \%)$, sangat setuju (25,8\%) kurang setuju (1,52\%) dan tidak setuju (1,52\%). Butir sembilan, bahwa Kembali ke alam adalah rujukan yang tepat unuk menjadikan lingkungan sebagai sumber inspirasi untuk membangun kecerdasan kebahasaan, yang menyatakan sangat setuju (50\%), setuju (43,9\%) kurang setuju (5\%) dan tidak setuju (1,5\%). Butir sepuluh, bahwa tema-tema pembelajaran bahasa Indonesia berbasis lingkungan merupakan sumber yang tak pernah habis dari benak (pengetahuan) manusia yang menyatakan setuju (50\%), sangat setuju (47\%) tidak setuju $(1,5 \%)$ dan kurang setuju $(1,5 \%)$. 
Berdasarkan hasil penelitian yang telah penulis lakukan, dapat disimpulkan bahwasannya lebih dari sebagian mahasiswa setuju tentang pentingnya materi mengenai lingkungan di sekolah khususnya pada pembelajaran bahasa Indonesia, bahkan ada yang menyatakan sangat setuju dengan ditambahkannya materi lingkungan dalam pembelajaran. Secara umum gambaran dari hasil angket yang penulis bagikan sangatlah baik dan positif, untuk itu kepada lembaga pendidikan di Indonesia tentu saja memiliki peran dan pengaruh yang besar untuk merealisasikan hal tersebut. Pemecahan masalah lingkungan yang dihadapi saat ini bukan hanya menjadi tanggungjawab pemerhati lingkungan saja, tetapi menjadi tanggungjawab kita seluruh kalangan masyarakat yang terlibat dalam masalah lingkungan.

\section{KEPUSTAKAAN}

Agustina, E. S. (2017). Pembelajaran Bahasa Indonesia Berbasis Teks: Representasi Kurikulum 2013. AKSARA: Jurnal Bahasa dan Sastra, 18(1).

Akhadiah, Sabarti, dkk. (1991). Bahasa Indonesia I. Jakarta:Depdikbud

Daryanto, Suprihatin. 2013. Pengantar Pendidikan Lingkungan Hidup. Yogyakarta. Penerbit Grava Media

Landriany, Ellen. (2014). Implementasi Kebijakan Adiwijaya dalam Upaya Mewujudkan Pendidikan Lingkungan Hidup di SMA Kota Malang. Jurnal Kebijakan dan Pengembangan Pendidikan. Vol 2, No.1.

Putri, D., \& Syahrul, R. (2019). Korelasi Keterampilan Membaca Pemahaman dan Keterampilan Menulis Teks Laporan Hasil Observasi Siswa Kelas Vii Smp Negeri 4 Pariaman. Pendidikan Bahasa Indonesia, 8(2), 62-69.

Ramadhan, S., Sukma, E., \& Indriyani, V. (2019, August). Environmental education and disaster mitigation through language learning. In IOP Conference Series: Earth and Environmental Science (Vol. 314, No. 1, p. 012054). IOP Publishing.

Ramadhan, Syahrul., Sukma., \& Indriyani, V. (2019). Enviromental Education and Disaster Mitigation Through Languange Learning. IOP Conference Series: Earth and Evironmental Science, 314, pp 14 
Sukma, E., Ramadhan, S., \& Indriyani, V. (2020, March). Integration of environmental education in elementary schools. In Journal of Physics: Conference Series (Vol. 1481, No. 1, p. 012136). IOP Publishing.

Syahrul Ramadhan, D., Suib Awrus, M. P., \& Wisdiarman, M. P. (2020). Analisis Kemampuan Guru Dalam Pelaksanaan Pembelajaran Seni Budaya Bidang Seni Rupa Berdasarkan Kurikulum 2013 Di Smpn 31 Padang. Serupa The Journal Of Art Education, 9(1).

Tulalessy, Q. D. (2016). Pembelajaran Bahasa Berbasis Lingkungan sebagai Upaya Membangun Kecerdasan Ekologis. Jurnal Triton Pendidikan, 1(1), 51-56. 